\title{
Persepsi Peternak Ayam Kampung Terhadap Penggunaan Mesin Tetas Otomatis di Kelompok Tani Budi Luhur Desa Kalipucang
}

\section{The Perception Of Kampung Chicken Livestock Analysis On The Use Of Automatic Hating Machines In Budi Luhur Famer Group Kalipucang Village}

\author{
Fuad Imam Mustaqim, Teguh Susilo, Suharti \\ Politeknik Pembangunan Pertanian Yogyakarta-Magelang \\ Jl. Magelang Kopeng Km 7, Tegalrejo, Magelang \\ Email : fuadimus@yahoo.co.id
}

Diterima : 25 Januari 2020

Disetuju : 6 April 2020

\begin{abstract}
ABSTRAK
Tujuan Penelitian yaitu untuk mengetahui persepsi peternak terhadap penggunaan mesin tetas otomatis beserta faktor-faktor yang mempengaruhi pesepsi terhadap penggunaan mesin tetas otomatis. Metode penelilian menggunakan jenis penelitian deskriptif analitis. Pengambilan sampel dilakukan dengan menggunakan metode sampel jenuh yaitu seluruh anggota dari Kelompok Tani Budi Luhur sejumlah 31 orang. Metode pengambilan data dilakukan dengan wawancara dan observasi. Variabel yang diukur merupakan variabel terikat yaitu: keuntungan relatif, kesesuaian, kerumitan, dapat dicoba serta dapat diamati. Variabel bebas yaitu umur, tingkat pendidikan, dan pengalaman beternak. Metode analisis yang digunakan adalah analisis skor median, dan analisis regresi linear berganda. Hasil penelitian menunjukkan bahwa persepsi peternak Kelompok Tani Budi Luhur secara keseluruhan adalah tidak baik. Hasil uji analisis regresi linear berganda secara simultan adalah nilai sig. 0,018, hal ini menunjukkan bahwa faktor umur, tingkat pendidikan dan pengalaman beternak berpengaruh signifikan $(p<0,05)$ terhadap persepsi peternak. Selanjutnya hasil uji analisis regresi linear berganda secara parsial adalah nilai signifikansi pada masing-masing variabel bebas yaitu umur berpengaruh signifikan dengan nilai $0,017 \quad(p<0,05)$; tingkat pendidikan tidak berpengaruh signifikan; dan pengalaman beternak berpengaruh seignifikan dengan nilai $0,020(p<0,05)$.
\end{abstract}

Kata kunci: Persepsi Peternak, Kelompok Tani, Mesin Tetas Otomatis

\begin{abstract}
The purpose of this Final Project is to find out farmers' perceptions of the use of automatic hatching machines and the factors that influence the perception of the use of automatic hatching machines.The research method uses descriptive analytical research. Sampling was carried out using the saturated sample method, namely all members of the Budi Luhur Farmer Group totaling 31 people. Data collection method is done by interview and observation. The measured variable is
\end{abstract}


the dependent variable, namely: relative profit, suitability, complexity, can be tried and can be observed. The independent variables are age, level of education, and experience of raising livestock. The analytical method used is the median score analysis, and multiple linear regression analysis. The results showed that the overall perception of farmers from the Budi Luhur Farmer Group was not good. Simultaneous multiple regression analysis test results are the value of sig. 0.018, this shows that the factors of age, level of education and experience of farmers have a significant effect $(p<0.05)$ on farmers' perceptions. Furthermore, the results of the multiple linear regression analysis test are partially the significance value of each independent variable, namely the age of significant effect with a value of 0.017 ( $p$ <0.05); education level did not significantly; and the experience of raising a significant effect with a value of 0.020 ( $p<0.05)$.

Key word: Perception Of Farmer, Farmer Group, Automatic Hatching Machines

\section{PENDAHULUAN}

Desa Kalipucang merupakan salah satu dari 22 desa yang terdapat di Kecamatan Grabag, Kabupaten Magelang. Desa Kalipucang terletak di wilayah beriklim tropis dengan ketinggian 675-700 mdpl, dengan curah hujan $659 \mathrm{~mm} /$ bulan dan suhu rata rata harian $18-29^{\circ} \mathrm{C}$. Sektor penggerak di daerah tersebut adalah pertanian dan peternakan.

Berdasarkan informasi dari Balai Penyuluhan Pertanian (BPP) Kecamatan Grabag bahwa Kelompok Tani Budi Luhur di Desa Kalipucang merupakan salah satu kelompok tani yang memiliki potensi untuk dikembangkan.

Permasalahan yang dapat diangkat dari informasi yang didapat melalui IPW adalah inovasi baru mengenai pembibitan/penetasan. Hal tersebut yang mendasari penulis untuk mengambil judul "Persepsi Peternak Ayam Kampung Terhadap Pengunaan Mesin Tetas Otomatis di Kelompok Tani Budi Luhur Desa Kalipucang".

Rumusan masalah berdasarkan latar belakang tersebut dapat dirumuskan masalah sebagai berikut: Belum diketahuinya persepsi peternak yang tergabung dalam Kelompok Tani Budi Luhur terhadap penggunaan mesin tetas otomatis. Belum diketahui sejauh mana pengaruh faktor-faktor karakteristik peternak (umur, tingkat pendidikan dan pengalaman beternak) terhadap persepsi peternak terhadap penggunaan mesin tetas otomatis.

Tujuan Tugas Akhir yaitu sebagai berikut: Mengetahui persepsi peternak yang tergabung dalam Kelompok Tani Budi Luhur terhadap penggunaan mesin tetas otomatis. Mengetahui sejauh mana faktor-faktor karakteristik peternak (umur, tingkat pendidikan dan pengalaman beternak) terhadap persepsi peternak terhadap penggunaan mesin tetas otomatis.

Penyuluhan dikenal secara luas dan dapat diterima oleh mereka yang bekerja di dalam organisasi pemberi jasa penyuluhan, tetapi tidak demikian halnya pada masyarakat luas. Salah satu pendidikan yang sifatnya non formal yang diberikan kepada petani disebut dengan penyuluhan pertanian (Hawkins, 2012).

Persepsi

merupakan pengorganisasian, penginterprestasian terhadap stimulus yang diinderanya sehingga merupakan suatu yang berarti dan merupakan respon yang integrated dalam diri individu (Walgito, 2010). Terdapat beberapa faktor yang mempengaruhi pemberntukan persepsi faktor-faktor tersebut adalah misalnya kebutuhan, suasana hati, pendidikan, 
pengalaman, masa lalu, social ekonomi, jenis kelamin dan umur (Robbin, 2003). Pengukuran berlandaskan pada karakteristik inovasi yaitu: keuntungan relative, kesesuaian, kerumitan, dapat dicoba, dan dapat diamati.

Penetasan merupakan upaya dalam mempertahankan populasi maupun memperbanyak jumlah daya tetas telur agar dapat diatur segala prosesnya serta dapat menghasilkan DOC yang berkualitas baik. Keberhasilan pada penetasan buatan, tergantung banyak faktor antara lain telur tetas, mesin tetas dan tata laksana penetasan (Kartasudjana dan Suprijatna, 2010). Mesin tetas otomatis adalah salah satu alat penetas modern dan didesain agar memungkinkan telur-telur dapat diputar secara otomatis berdasarkan waktu ataupun timer yang sudah ditentukan sebelumnya. Ini akan membantu mengurangi tenaga manusia secara signifikan dan menghemat waktu dalam proses pembalikan (Paimin, 2011).

\section{MATERI DAN METODE}

Pelaksanaan kegiatan Tugas Akhir dilaksanakan pada tanggal 2 Maret 2020 - 2 Mei 2020. Kegiatan Tugas Akhir dilaksanakan di Desa Kalipucang, Kecamatan Grabag, Kabupaten Magelang, Provinsi Jawa Tengah. Alat yang digunakan dalam pelaksanaan kajian penyuluhan ini meliputi: 1) Kuesioner, 2) Kamera, 3) Laptop, 4) slide powerpoint dan 5) Leaflet. Sedangkan bahan yang akan digunakan alat tulis dan kertas HVS A4 80 gram.

Kegiatan penyuluhan dilakukan dengan metode pendekatan kelompok dengan teknik ceramah, diskusi. Kemudian dilakukan pengukuran persepsi menggunakan kuesioner setelah kegiatan penyuluhan sebagai stimulus.
Populasi dari pengkajian ini adalah anggota Kelompok Tani Budi Luhur Desa Kalipucang dengan jumlah anggota aktif 31 orang. Sedangkan Penarikan sampel untuk kegiatan evaluasi menggunakan metode sampling jenuh, yaitu teknik penentuan sampel dimana seluruh anggota populasi dijadikan sampel dengan jumlah 31 orang.

Sumber data primer merupakan hasil observasi dan wawancara dengan anggota kelompok tani Budi Luhur. Kegiatan observasi dilakukan dengan melakukan pengamatan langsung di Desa Kalipucang. Sedangkan wawancara dilakukan secara langsung dengan responden yang berhubungan dengan karakteristik responden.

Data sekunder merupakan data yang dikumpulkan dari tangan kedua atau dari sumber-sumber lain yang telah tersedia sebelum penelitian dilakukan. Data sekunder diidapat dari data keadaan penduduk Desa Kalipucang, Kecamatan Grabag, Kabupaten Magelang.

Instrumen utama yang digunakan dalam penelitian adalah daftar pertanyaan (kuisioner) yang disebarkan kepada responden. Instrumen yang dibuat sebelum disebarkan kepada responden yang menjadi sampel penelitian terlebih dahulu harus dilakukan uji validitas dan reliabilitas (Sugiyono, 2011).

Kuisioner memegang peranan penting dalam menentukan mutu suatu penelitian dari tingkat validitas atau kesahihan data dan reliabilitas atau dapat dipercaya, sebelum kuesioner disebarkan ke responden yang menjadi sasaran yaitu peternak ayam kampung di Desa Kalipucang, terlebih dahulu kuesioner diuji validitas dan reliabilitasnya dengan menyebarkan ke beberapa responden diluar sampel yang menjadi obyek peneliti. Bila koefisien kolerasi sama dengan 0,3 atau lebih maka butir instrumen dinyatakan valid, 
sedangkan suatu instrumen dinyatakan reliabel bila koefisien reliabilitas minimal 0,6 (Sugiyono, 2014).

Analisis deskriptif merupakan analisis dengan mendeskripsikan suatu data yang mengacu pada transformasi data mentah ke dalam suatu bentuk yang mudah dipahami atau di mengerti dan ditafsirkan dari data atau angka yang ditampilkan. Kegunaan analisis deskriptif adalah untuk menggambarkan suatu jawaban-jawaban observasi dan disajikan dengan menggunakan tabel distribusi frekuensi. Skoring dapat kategorikan sebagai berikut: sangat setuju $(S S)=5$, setuju $(S)=4$, ragu-ragu $(R)=3$, tidak setuju $(T S)=2$, dan sangat tidak setuju (STS) =1 (Azwar, 2010).

Pengukuran persepsi dilakukan menggunakan analisis skor median dengan rumus sebagai berikut:

$\mathrm{Q} 2=x\left(\frac{\mathrm{n}+1}{2}\right)$

Keterangan :

$\mathrm{x} \quad$ : Nilai data pada $\mathrm{n}$ sampel

$\mathrm{n}$ : Jumlah sampel

Q2 : Kuartal tengah

Analisis inferensial dilakukan untuk mengetahui faktor karakteristik peternak yang mempengaruhi persepsi. Analisis inferensial ini menggunakan analisis regresi linear berganda. Model persamaan analisis regresi linear berganda sebagai berikut :

$$
\mathrm{Y}=\mathrm{a}+\mathrm{b} 1 \mathrm{X} 1+\mathrm{b} 2 \mathrm{X} 2+\mathrm{b} 3 \mathrm{X} 3+\mathrm{e}
$$

Gambar 2. Rumus Persamaan Analisis
Regresi Linear berganda

$\mathrm{Y}=$ Respons Peternak.

a $\quad$ Konstanta.

$\mathrm{b} \quad=$ Koefisien Regresi.

$\mathrm{X} 1=$ Umur

$\mathrm{X} 2=$ Tingkat Pendidikan.

$\mathrm{X} 3=$ Pengalaman Beternak.

$\mathrm{E}=$ Eror, menunjukan tingkat fluktuasi dari pendugaan.

Signifikansi pengaruh variabel independen (umur, tingkat pendidikan, pengalaman beternak) terhadap variabel dependen (persepsi) dilihat dari nilai hasil uji $F$ dan Uji T.

\section{HASIL DAN PEMBAHASAN}

Persepsi diukur menggunakan kuesioner yang berdasar pada 5 karakteristik inovasi (keuntungan relatif, kesesuaian, kerumitan, dapat dicoba, dapat diamati). Kemudian yang terakhir ialah persepsi peternak terhadap sebuah inovasi yaitu penggunaan mesin tetas otomatis

\section{Persepsi Responden Terhadap Karakteristik Inovasi Penggunaan Mesin Tetas Otomatis Sesuai Pernyataan Keuntungan Relatif \\ Keuntungan relatif dinilai} berdasarkan jawaban responden terhadap 3 pertanyaan (kuesioner). NIlai dari kuesioner tersebut dapat dilihat pada tabel dibawah ini.

Tabel 1. Persepsi Responden Aspek Pernyataan Keuntungan Relatif

\begin{tabular}{lccccr}
\hline $\begin{array}{c}\text { Persepsi } \\
\text { Responden }\end{array}$ & $\begin{array}{c}\text { Jumlah } \\
\text { Responden }\end{array}$ & $(\%)$ & Rata - Rata & Kisaran & Skor Median \\
\hline Baik & 23 & 74,19 & 12,09 & $8-14$ & 12 \\
Tidak Baik & 8 & 25,81 & & & \\
\hline Jumlah & $\mathbf{3 1}$ & $\mathbf{1 0 0}$ & & & \\
\hline
\end{tabular}

Sumber: Data diolah (2020)

Diketahui bahwa persepsi baik responden dilihat dari aspek tingkat keuntungan relatif sebanyak 23 orang, dengan nilai total skor $\geq$ median 
Persepsi tidak baik sebanyak 8 orang, dengan nilai total skor < median. Ratarata perolehan total skor jawaban responden adalah 12,09 dengan nilai median yaitu 12. Perolehan total skor terendah pada kuesioner aspek keuntungan relatif yaitu 8 dan perolehan total skor tertinggi adalah 14 .
Karakteristik Inovasi Penggunaan Mesin Tetas Otomatis Sesuai Pernyataan Kesesuaian

Kesesuaian dinilai berdasarkan jawaban responden terhadap 3 pertanyaan (kuesioner). Nilai dari kuesioner tersebut dapat dilihat pada tabel dibawah ini.

\section{Persepsi Responden Terhadap}

Tabel 2. Persepsi Responden Aspek Pernyataan Kesesuaian

\begin{tabular}{lrrrrr}
\hline $\begin{array}{c}\text { Persepsi } \\
\text { Responden }\end{array}$ & $\begin{array}{l}\text { Jumlah } \\
\text { Responden }\end{array}$ & $(\%)$ & Rata - Rata & Kisaran & Skor Median \\
\hline Baik & 16 & 51,61 & 12,61 & $10-15$ & 13 \\
Tidak Baik & 15 & 48,39 & & & \\
\hline Jumlah & $\mathbf{3 1}$ & $\mathbf{1 0 0}$ & & & \\
\hline
\end{tabular}

Sumber: Data diolah (2020)

Diketahui bahwa persepsi baik responden dilihat dari aspek tingkat kesesuaian sebanyak 16 orang, dengan nilai total skor $\geq$ median. Persepsi tidak baik sebanyak 15 orang, dengan nilai total skor < median. Rata-rata perolehan total skor jawaban responden adalah 12,61 dengan nilai median yaitu 13 . Perolehan total skor terendah pada kuesioner aspek kesesuaian yaitu 10 dan perolehan total skor tertinggi adalah 15.
3. Persepsi Responden Terhadap Karakteristik Inovasi Penggunaan Mesin Tetas Otomatis Sesuai Pernyataan Kerumitan

Kerumitan dinilai berdasarkan jawaban responden terhadap 3 pertanyaan (kuesioner). Hasil dari kuesioner tersebut dapat dilihat pada tabel dibawah ini.

Tabel 3. Persepsi Responden Aspek Pernyataan Kerumitan

\begin{tabular}{lrrrrr}
\hline $\begin{array}{c}\text { Persepsi } \\
\text { Responden }\end{array}$ & $\begin{array}{l}\text { Jumlah } \\
\text { Responden }\end{array}$ & $(\%)$ & Rata - Rata & Kisaran & Skor Median \\
\hline Baik & 21 & 67,74 & 12,35 & $10-14$ & 12 \\
Tidak Baik & 10 & 32,26 & & & \\
\hline Jumlah & $\mathbf{3 1}$ & $\mathbf{1 0 0}$ & & & \\
\hline
\end{tabular}

Sumber: Data diolah (2020)

Diketahui bahwa persepsi baik responden dilihat dari aspek tingkat kerumitan sebanyak 21 orang, dengan nilai total skor $\geq$ median. Persepsi tidak baik sebanyak 10 orang, dengan nilai total skor < median. Rata-rata perolehan total skor jawaban responden adalah 12,35 dengan nilai median yaitu 12 . Perolehan total skor terendah pada kuesioner aspek kerumitan yaitu 10 dan perolehan total skor tertinggi adalah 14

\section{Persepsi Responden Terhadap Karakteristik Inovasi Penggunaan Mesin Tetas Otomatis Sesuai Pernyataan Dapat Dicoba}

Dapat dicoba dinilai berdasarkan jawaban responden terhadap 3 pertanyaan (kuesioner). Hasil dari kuesioner tersebut dapat dilihat pada 
tabel dibawah ini.

Tabel 4. Persepsi Responden Aspek Pernyataan Dapat Dicoba

\begin{tabular}{lrrrrr}
$\begin{array}{c}\text { Persepsi } \\
\text { Responden }\end{array}$ & $\begin{array}{l}\text { Jumlah } \\
\text { Responden }\end{array}$ & $\mathbf{( \% )}$ & Rata - Rata & Kisaran & Skor Median \\
\hline Baik & 26 & 83,87 & 12,58 & $11-15$ & 12 \\
Tidak Baik & 5 & 16,13 & & & \\
\hline Jumlah & $\mathbf{3 1}$ & $\mathbf{1 0 0}$ & & & \\
\hline
\end{tabular}

Sumber: Data diolah (2020)

Diketahui bahwa persepsi baik responden dilihat dari aspek dapat dicoba sebanyak 26 orang, dengan nilai total skor $\geq$ median. Persepsi tidak baik sebanyak 5 orang, dengan nilai total skor < median. Rata-rata perolehan total skor jawaban responden adalah 12,58 dengan nilai median yaitu 12. Perolehan total skor terendah pada kuesioner aspek dapat dicoba yaitu 11 dan perolehan total skor tertinggi adalah 15.
5. Persepsi Responden Terhadap Karakteristik Inovasi Penggunaan Mesin Tetas Otomatis Sesuai Pernyataan Dapat Diamati

Dapat diamati dinilai berdasarkan jawaban responden terhadap 3 pertanyaan (kuesioner). Hasil dari kuesioner tersebut dapat dilihat pada tabel dibawah ini.

Tabel 5. Persepsi Responden Aspek Pernyataan Dapat Diamati

\begin{tabular}{lrrrrr}
$\begin{array}{c}\text { Persepsi } \\
\text { Responden }\end{array}$ & $\begin{array}{l}\text { Jumlah } \\
\text { Responden }\end{array}$ & (\%) & Rata - Rata & Kisaran & Skor Median \\
\hline Baik & 19 & 61,29 & 12,61 & $11-15$ & 13 \\
Tidak Baik & 12 & 38,71 & & & \\
\hline Jumlah & $\mathbf{3 1}$ & $\mathbf{1 0 0}$ & & & \\
\hline
\end{tabular}

Sumber: Data diolah (2020)

Diketahui bahwa persepsi baik responden dilihat dari aspek dapat diamati sebanyak 19 orang, dengan nilai total skor $\geq$ median. Persepsi tidak baik sebanyak 12 orang, dengan nilai total skor < median. Rata-rata perolehan total skor jawaban responden yaitu 12,61 dengan nilai median yaitu 13. Perolehan total skor terendah pada kuesioner aspek dapat diamati yaitu 11 dan perolehan total skor tertinggi adalah 15 .

\section{Persespsi Terhadap Inovasi}

Walgito (2010) menyatakan bahwa, persepsi merupakan pengorganisasian, penginterprestasian terhadap stimulus yang diinderanya sehingga merupakan suatu yang berarti dan merupakan respon yang integrated dalam diri individu.

Tabel 6. Persepsi Responden Terhadap Inovasi

\begin{tabular}{lrrrrr}
\hline $\begin{array}{c}\text { Persepsi } \\
\text { Responden }\end{array}$ & $\begin{array}{c}\text { Jumlah } \\
\text { Responden }\end{array}$ & $\begin{array}{c}\text { Persentase } \\
(\%)\end{array}$ & $\begin{array}{c}\text { Rata- } \\
\text { rata }\end{array}$ & Kisaran & $\begin{array}{c}\text { Skor } \\
\text { Median }\end{array}$ \\
\hline Baik & 16 & 51,61 & 62,25 & $56-69$ & 63 \\
\hline Tidak Baik & 15 & 48,39 & & & \\
\hline Jumlah & $\mathbf{3 1}$ & $\mathbf{1 0 0 , 0 0}$ & & & \\
\hline
\end{tabular}

Sumber: Data diolah (2020)

Tabel di atas menunjukkan bahwa persepsi responden sebanyak 31 orang 
terhadap penggunaan mesin tetas otomatis yaitu 16 orang memiliki persepsi baik, dengan nilai total skor $\geq$ median. Persepsi tidak baik terhadap penggunaan mesin tetas otomatis sebanyak 15 orang, dengan nilai total skor < median. Rata-rata perolehan total skor jawaban responden yaitu 62,25 dengan nilai median yaitu 63 .

Analisis inferensial digunakan untuk menjawab tujuan yang ke 2 yaitu faktor-faktor yang mempengaruhi persepsi yang diantaranya yaitu umur, tingkat pendidikan dan pengalaman beternak, analisis ini menggunakan regresi linear berganda. Signifikansi pengaruh variabel independen (umur, tingkat pendidikan, pengalaman beternak) terhadap variabel dependen (persepsi) dihitung menggunakan aplikasi SPSS yang dapat dilihat dari nilai hasil uji uji $F$ (tabel Anova ${ }^{a}$ ), uji $T$ (tabel Coefficients ${ }^{\mathrm{a}}$ ), dan uji determinasi atau uji R (output tabel model summary).

\section{Pengaruh Karakteristik Responden Secara Simultan Terhadap Persepsi Peternak (Uji F).}

Uji F merupakan tahapan awal mengidentifikasi model regresi yang diestimasi layak atau tidak. Layak disini maksudnya adalah model yang diestimasi layak digunakan untuk menjelaskan pengaruh variabel-variabel bebas terhadap variabel terikat. Hasil Analisis Uji $\mathrm{F}$ dapat dilihat pada tabel berikut :

Tabel 7. Hasil Analisis Uji F

\begin{tabular}{llrrrrr}
\hline Model & \multicolumn{1}{c}{$\begin{array}{c}\text { Sum of } \\
\text { Squares }\end{array}$} & Df & $\begin{array}{c}\text { Mean } \\
\text { Square }\end{array}$ & F & Sig. \\
\hline & Regression & 4,975 & 3 & 1,658 & 3,991 &, $018^{\mathrm{b}}$ \\
1 & 11,218 & 27 &, 415 & & \\
\hline & Residual & 16,194 & 30 & & & \\
& Total & & & & & \\
\hline
\end{tabular}

Sumber: Data diolah (2020)

a. Dependent Variable: Persepsi

b. Predictors: (Constant), Pengalaman, Umur, Pendidikan

Berdasarkan tabel di atas diketahui nilai sig. pada kajian ini yaitu 0,018 lebih kecil dari 0,05 sehingga menunjukkan bahwa model regresi linear yang diestimasi layak digunakan untuk menjelaskan pengaruh variabel bebas (umur, tingkat pendidikan, pengalaman beternak) terhadap persepsi peternak terhadap penggunaan mesin tetas otomatis.
2. Pengaruh Responden Secara Parsial Terhadap Persepsi Peternak (Uji t).

Uji t digunakan untuk menjelaskan pengaruh dari variabel bebas terhadap variabel terikat secara parsial atau individual. Hasil analisis uji $t$ ini dapat dilihat pada tabel berikut : 
Tabel 8. Hasil Analisis Uji t

\begin{tabular}{|c|c|c|c|c|c|c|}
\hline \multirow{2}{*}{\multicolumn{2}{|c|}{ Model }} & \multicolumn{2}{|c|}{$\begin{array}{l}\text { Unstandardized } \\
\text { Coefficients }\end{array}$} & \multirow{2}{*}{$\begin{array}{c}\begin{array}{c}\text { Standardized } \\
\text { Coefficients }\end{array} \\
\text { Beta }\end{array}$} & \multirow[t]{2}{*}{$\mathbf{T}$} & \multirow[t]{2}{*}{ Sig. } \\
\hline & & B & Std. Error & & & \\
\hline \multirow{4}{*}{1} & & 4.577 & .889 & & & .00 \\
\hline & Um & .410 & .16 & .417 & 546 & .017 \\
\hline & Tingkat Pend & -.186 & .187 & -.242 & -.994 & .329 \\
\hline & Pengalaman & -.273 & .110 & -.609 & -2.466 & .02 \\
\hline
\end{tabular}

Sumber: Data diolah (2020)

Berdasarkan tabel di atas diketahui nilai signifikansi pada masingmasing variabel bebas yaitu: umur bernilai 0,017 ; tingkat pendidikan bernilai 0,329 ; dan pengalaman beternak bernilai 0,020 . Sehingga menunjukkan bahwa umur dan pengalaman beternak berpengaruh signifikan terhadap persepsi peternak. Sementara tingkat pendidikan tidak berpengaruh terhadap persepsi peternak.

Berikut penjelasan pengaruh variabel independen secara parsial, terhadap variabel dependen.

\section{a. Umur (X1).}

Berdasarkan hasil perhitungan untuk variabel umur diproleh bahwa nilai signifikansi sebesar 0,017 atau lebih kecil dari 0,05. Sehingga dapat disimpulkan bahwa variabel umur berpengaruh signifikan terhadap persepsi peternak. Hal ini dikarenakan semua responden yang berjumlah 31 orang merupakan usia produktif. Badan Pusat Statistik (2019) menyatakan bahwa kelompok usia produktif berada dalam rentang usia 15-64 tahun. Hal ini sesuai dengan pendapat Hasyim (2006) bahwa karakteristik umur dapat mempengaruhi produktifitas seseorang dalam melakukan aktifitas sehari hari, jika kondisi umur masih produktif maka kemungkinan besar seseorang dapat bekerja dengan baik dan maksimal.

\section{b. Tingkat pendidikan (X2).}

Berdasarkan hasil perhitungan untuk variabel tingkat pendidikan nilai signifikansi yaitu sebesar 0,329 lebih besar dari 0,05. Disimpulkan bahwa variabel tingkat pendidikan tidak berpengaruh terhadap persepsi peternak. Hal ini dikarenakan mayoritas responden memiliki tingkat pendidikan yang tergolong merata dapat dilihat pada Lampiran 8 bahwa mayoritas responden memiliki pendidikan STLP yaitu sebanyak 11 orang kemudian disusul dengan lulusan SD 9 orang dan lulusan SLTA 9 orang. Sesuai dengan pendapat Suhardjo (2007) yang menyatakan bahwa pendidikan formal yang cukup dapat membentuk nilai bagi seseorang terutama dalam menerima suatu hal baru. Hikmah dkk. (2019) menambahkan bahwa dalam mempersepsi suatu teknologi baru, tidak tergantung pada tingkat pendidikan yang dimilki oleh peternak. Peternak yang berpendidikan tinggi maupun rendah rata-rata sama yaitu menjawab bahwa penggunaan mesin tetas otomatis dalam kategori baik dan dianggap dapat diterima oleh semua kalangan.

\section{c. Pengalaman beternak (X3).}

Berdasarkan hasil perhitungan untuk variabel pengalaman beternak nilai signifikansi 0,020 atau lebih kecil dari 0,05 . Sehingga dapat disimpulkan bahwa variabel pengalaman beternak berpengaruh signifikan terhadap persepsi peternak. Roswida (2013) menyatakan bahwa lama waktu petani dalam menjalankan usaha taninya akan berpengaruh terhadap pengambilan keputusan dalam menerima suatu inovasi baru. 


\section{Uji Determinasi}

Uji determinasi ini digunakan ntuk mengetahui proporsi pengaruh dari seluruh variabel bebas terhadap variabel terikat. Sehingga dapat diketahui nilai yang berpengaruh dalam model regresi. Nilai determinasi dapat dilihat pada Tabel 9.

Tabel 9. Uji Determinasi $\left(R^{2}\right)$

\begin{tabular}{lrrrrr}
\hline Model & R & R Square & $\begin{array}{c}\text { Adjusted R } \\
\text { Square }\end{array}$ & $\begin{array}{l}\text { Std. Error of } \\
\text { the Estimate }\end{array}$ & $\begin{array}{l}\text { Durbin- } \\
\text { Watson }\end{array}$ \\
\hline 1 & $.554^{\mathrm{a}}$ & .307 & .230 & .64459 & 1.520
\end{tabular}

Sumber: Data diolah (2020)

a. Predictors: (Constant), Pengalaman, Umur, Pendidikan

b. Dependent Variable: Persepsi

Berdasarkan Tabel 9 hasil uji determinasi diperoleh nilai $R$ Square $\left(R^{2}\right)$ sebesar 0,307. Yang artinya kemampuan variabel independen (umur, tingkat pendidikan, dan pengalaman sebesar $30,7 \%$ sedangkan sisanya 69,3 $\%$ dijelaskan oleh variabel lain. Sugiyono (2013) mengungkapkan bahwa nilai yang hampir mendekati satu berarti variabel - variabel independen memberikan hampir semua informasi yang dibutuhkan untuk memprediksi variasi dependen, artinya semakin besar pengaruh variabel independen terhadap variabel dependen.

Teknik analisis dalam penelitian menggunakan analisis regresi linear berganda, dengan tujuan mengetahui pengaruh variabel bebas dengan variabel terikat. Model persamaan regresi linear berganda adalah sebagai berikut :

$$
Y=4,57+0,41 X_{1}-0,186 X_{2}-0,273 X_{3}
$$

Konstanta sebesar 4,57 artinya apabila umur, tingkat pendidikan, dan pengalaman beternak tidak ada atau nilainya adalah 0 , maka persepsi peternak terhadap penggunaan mesin tetas otomatis adalah 4,57. Dari persamaan di atas dapat diketahui jika, apabila umur mengalami kenaikan satu tahun maka persepsi akan mengalami kenaikan sebesar 0,41 satuan dan apabila pengalaman berternak mengalami kenaikan satu tahun persepsi akan mengalami penurunan sebesar 0,273 satuan. Sementara tingkat pendidikan diketahui tidak memiliki pengaruh setelah dilakukan uji t.

Efektivitas penyuluhan diukur menggunakan total skor yang didapat pada masing-masing aspek karakteristik inovasi yang meliputi keuntungan relatif, tingkat kesesuaian, tingkat kerumitan, kemudahan untuk dicoba, dan kemudahan untuk diamati. Berikut adalah data mengenai total skor jawaban berdasarkan karakteristik inovasi:

Tabel 10. Total Skor Jawaban Berdasar Karakteristik Inovasi

\begin{tabular}{lr}
\hline \multicolumn{1}{c}{ Karakteristik } & Jumlah \\
\hline Keuntungan relatif & 375 \\
Kompatibel & 391 \\
Kompleksitas & 383 \\
Triabilitas & 390 \\
Dapat diamati & 391 \\
\hline \multicolumn{1}{c}{ Jumlah } & $\mathbf{1 . 9 3 0}$
\end{tabular}

Sumber: Data diolah (2020)

Efektivitas penyuluhan menurut Susanto dan Suryana (2014) dapat dianalisis menggunakan rumus sebagai berikut :

Efektivitas Penyuluhan

$=\frac{\text { Jumlah Skor Keseluruhan }}{\text { Jumlah Skor Maksimal }}$ X 100\%

Efektivitas Penyuluhan 
$=\frac{1930}{2325} \times 100 \%$

Efektivitas Penyuluhan

$=83,01 \%$

Berdasarkan hasil perhitungan, dapat diketahui bahwa nilai efektivitas penyuluhan sebesar 83,01 \%. Hal tersebut menandakan bahwa kegiatan penyuluhan tergolong sangat efektif. Hal ini sesuai dengan pendapat Susanto dan Suryana (2014) bahwa tingkat efektivitas dikategorikan sesuai kriteria dengan skor 0 sampai dengan $20 \%$ = tidak efektif, skor $21 \%$ sampai dengan $40 \%=$ kurang efektif, skor $41 \%$ sampai dengan $60 \%=$ cukup efektif, skor $61 \%$ sampai dengan $80 \%=$ efektif, dan skor $81 \%$ sampai dengan $100 \%$ = sangat efektif.

Efektivitas merupakan suatu ukuran yang menyatakan seberapa jauh target (kualitas, kuantitas, waktu) yang telah tecapai. Dimana makin besar persentase target yang dicapai, makin tinggi efektivitasnya. Hasil perhitungan tersebut menandakan bahwa kegiatan penyuluhan dengan metode pendekatan kelompok dan pendekatan individu yang dilakukan dengan teknik ceramah, diskusi, dan demonstrasi cara cukup berpengaruh dan berdampak baik terhadap materi penyuluhan yang disampaikan. Hal ini sesuai dengan pendapat Mardikanto (2010), yang menyatakan bahwa efektivitas penyuluhan yang telah dilakukan didukung oleh beberapa faktor, antara lain metode penyuluhan, media penyuluhan, materi penyuluhan, serta tempat dan waktu penyuluhan.

\section{KESIMPULAN}

Persepsi peternak terhadap penggunaan mesin tetas otomatis dalam kategori tidak baik. Hal ini dikarenakan rata-rata nilai total skor jawaban responden berada dibawah nilai median nilai total skor jawaban responden. Model regresi linear diestimasi layak digunakan untuk menjelaskan pengaruh variabel bebas (umur, tingkat pendidikan, pengalaman beternak) terhadap persepsi peternak terhadap penggunaan mesin tetas otomatis. Umur dan pengalaman beternak berpengaruh signifikan terhadap persepsi, sementara tingkat pendidikan tidak berpegaruh kepada persepsi peternak terhadap penggunaan mesin tetas otomatis.

Sebagian peternak dengan persepsi baik terhadap penggunaan mesin tetas otomatis memiliki peluang untuk mengembangkan potensinya. Oleh karena itu diharapkan ada tindak lanjut pihak terkait dalam hal ini BPP Kecamatan Grabag maupun Kelompok Tani Budi Luhur terhadap kajian Tugas Akhir yang telah dilakukan oleh mahasiswa sehingga diharapkan inovasi berupa penggunaan mesin tetas otomatis yang telah disuluhkan dapat diterapkan oleh peternak anggota Kelompok Tani Budi Luhur.

\section{DAFTAR PUSTAKA}

Azwar, S. 2010. Sikap Manusia Teori dan Pengukurannya. Pustaka Pelajar, Yogyakarta.

Badan Pusat Statistik. 2019. Istilah Angka Beban Tanggungan. Diakses $30 \quad$ Mei 2020. https://www.bps.go.id/istilah/index .html? Istilah_page=4

Hasyim, Hasman. 2006. Analisis Hubungan Karakteristik Petani Kopi Terhadap Pendapatan (Studi Kasus: Desa Dolok Saribu Kecamatan Paguran Kabupaten Tapanuli Utara). Jurnal Komunikasi Penelitian Vol 18 (1) 2006.

Hawkins dan Van Den Ban. 2012. Penyuluhan Pertanian. Kanisius, Yogyakarta.

Hikmah, Evita. Nurdayati. Hartati, Puji. 2019. Persepsi Peternak Terhadap Teknologi Pembuatan 
Telur AsinMenggunakan Alat Pemanas Buatan. Jurnal Pengembangan Penyuluhan Peternakan. Volume 16 (29), Juli 2019: 80-90 Diakses 21 Juli 2020. http://jurnal.polbangtanyoma.ac.id /index.php/jp3/index

Kartasudjana dan Suprijatna, E. 2010. Manajemen Ternak Unggas. Penebar Swadaya, Jakarta.

Mardikanto, T. 2010. Sistem Penyuluhan Pertanian. Program Studi Pemberdayaan Masyarakat, Program Studi Pascasarjana, Universitas Sebelas Maret, Surakarta.

Paimin, F.B. 2011. Mesin Tetas. Penebar Swadaya, Jakarta.

Robbin. 2003. Perilaku Organisasi. Jilid I, PT. Indeks Kelompok Gramedia, Jakarta.

Roswida, R. 2013. Tahapan Proses Keputusan Adopsi Inovasi Pengendalian Hama Penyakit Tanaman Dengan Agensi Hayati Kasus Petani Sayur Di Kecamatan Banuhampu dan Sungai Puar Kabupaten Agam Sumatera Barat. Institus Pertanian Bogor

Sugiyono. 2014. Metode Penelitian Pendidikan Pendekatan Kuantitatif, Kualitatif Dan R\&D. Alfabeta, Bandung. . 2013. Metode Penelitian

Pendidikan Pendekatan Kuantitatif, Kualitatif, dan R\&D. Alfabeta, Bandung. 2011. Metode Penelitian Administratif. Alfabeta, Bandung.

Suhardjo, Drajat. 2007. Definisi Tingkat Pendidikan. Yogyakarta. Universitas Islam Indonesia. Yogyakarta Press.

Susanto dan Suryana, 2014. Respon Peternak Terhadap Pemberian Urea Molases Multinutrient Block (UMMB) Sebagai Pakan Penguat Pada Sapi Bali Di Desa Sumber
Mulya Kecamatan Pelaihari Tanah Laut. Diakses Tanggal 24 April 2020. http://kalsel.litbang.pertanian. go.id/ind/images/pdf/semnas2014 158_susanto.pdf. 
